\title{
Testing a fit-for-purpose (FFP) model for strengthening customary land rights and tenure to improve household food security in Northwest Ghana
}

\author{
Baslyd B. Nara ${ }^{\text {a,*, }}$, Monica Lengoiboni ${ }^{\mathrm{b}}$, J.A. Zevenbergen ${ }^{\mathrm{b}}$ \\ ${ }^{a}$ Dept of Real Estate \& Land Mgt, University of Business \& Integrated Development Studies, Wa, Ghana \\ ${ }^{\mathrm{b}}$ Dept of Urban \& Regional Planning \& Geo-Info. Mgt, University of Twente, The Netherlands
}

\section{A R T I C L E I N F O}

\section{Keywords:}

Fit-for-purpose

Customary land rights

Northwest Ghana

Food security

\begin{abstract}
A B S T R A C T
Current land rights and tenure literature on northern Ghana is deficient in presenting a responsible and fit-forpurpose land rights and tenure model (in short: FFP model) for subsistence farmers. This paper tests a new cocreated FFP model based on user requirements. The research tested the effectiveness, proper functioning and possible obstructions to the model when implemented. In order to test this model; focus group discussions, key informant interviews, joint community workshops and community forums were employed. The results show that the co-created model is potentially effective, can function properly with minimal obstructions that can be easily addressed if there is commitment from stakeholders. The model can therefore facilitate the strengthening of land rights and securing of land tenure in local communities. It further passed the test as capable of facilitating subsistence farming and the promoting food security. The research (test) also shows that in spite of the external influences negatively affecting local communities including their land issues, these communities are willing to take advantage of some of these external factors (e.g. government institutions, legislations and courts) for their common good. Thus, strengthening land rights and securing tenure for all categories of land users and land uses. The research therefore concludes that this model can be successfully implemented in the study area and in other areas of Ghana. However, beyond Ghana, some adjustments to the model may be needed to make it adequately relevant for each unique context.
\end{abstract}

\section{Introduction}

Land is a fundamental source of livelihood for most people in the world. It contains various rights that people can lay claim to, through inheritance, purchase or other means. In other words, these land rights are the entitlements and practices that communities use to make land available to various categories of users and uses. Some people, the landowners usually hold primary and strong land rights while others e.g. settlers generally hold weaker secondary rights (Bugri, 2010; Nara et al., 2020a). Those who possess weak land rights tend to produce insufficient food from their farms and are consequently more prone to experiencing food insecurity (Nara et al., 2020a; Peters, 2013). Meanwhile, food security of many subsistence farmers especially in sub-Saharan Africa, Asia and southern America largely depend directly on strong land rights and secure tenure (Bugri, 2010; Cotula and Neves, 2007; Nara et al., 2020a). This probably explains why the UN explicitly captured food security in its Sustainable Development Goals (SDGs) 1 \& 2 . Additionally in sub-Saharan Africa, where there is low application of agricultural mechanisation coupled with land rights and tenure challenges, many farmers still require large amounts of land to produce sufficient food (Federal Ministry of Food and Agriculture BMLE, 2015; Ruerd, 2011). Meanwhile, weak customary land rights and insecure tenure issues of marginalised subsistence farmers characterise many land dealings in these areas (Cotula and Neves, 2007).

\subsection{Debates surrounding use of models for securing tenure}

There are many debates surrounding the usefulness of models for securing land tenure, promoting land-based production like farming and securing food. Such models are usually tailored towards dealing with specific tenure issues and in particular contexts. One of such models is the vulnerability to food insecurity model (Capaldo et al., 2010). This model establishes the relationship between assets like land i.e. ownership and its influence on vulnerability to food insecurity due to shocks that affect agricultural production. The model asserts that there can be chronic food insecurity associated with land "ownership" and those earning income from on-farm activities. The suggestion then is that farming can expose households to food insecurity shocks with lasting

\footnotetext{
* Correspondence to: SD Dombo University of Business and Integrated Development Studies, Wa, P. O. Box UPW3 Ghana.
} 
negative consequences if the right tenure strategies for instance, are not adopted. Accordingly, models seek to facilitate an assessment of a problem and provide the framework for dealing with them holistically (Nara et al., 2020b). The model by Capaldo et al. allows for an analysis of how vulnerability relates with various household characteristics, in order to profile the most vulnerable households and to draw conclusions on possible causes of vulnerability to food security. This model also engages in poverty analysis based on various unspecified risk factors to analyse food security. However, this paper "mock-tested" the new responsible and fit-for-purpose land rights and tenure model's (in short: FFP model) possible success when implemented based on a specific risk factor i.e. weak land rights and insecure tenure of the end users. There is the need for a FFP model in Ghana because using the current local customary and formal/legal systems side-by-side to manage lands has challenges which the FFP model is apparently successful in addressing from Enemark's works. Hence, the model by Capaldo et al. is based on the social risk management approach where previously unknown factors are risks of different kinds. Therefore, households' risk management abilities of these uncertainties like weak land rights and insecure land tenure issues determine the future food (in)security status. Their model explains how current characteristics, risks and risk management capacities affect the likelihood of a favourable (or unfavourable) future food security status.

A second model assessed in this work is a land tenure model (Mulolwa, 2002). This model examines land tenure and land reforms in a few sub-Saharan African countries. The analysis reveals the reasons for reforms and the resulting insecure land tenure in the sub-region. Given this nature of tenure challenges in sub-Saharan Africa and the arguments for or against, the case is then made for an alternative model (Mulolwa, 2002). The argument is further made as to whether customary tenure in its current form and practices is or not an obstacle to stronger land rights and tenure security. Mulolwa subsequently recommended a kind of a model, believed to be effective in particular contexts to promote land rights, land tenure security and consequent productive use of land for example for farming. The result of Mulolwa's recommendation is expected to lead to attainment of human aspirations, following strong land rights and secure tenure, which can lead to improved food production, food availability and food security.

Another model by Chigbu and Klaus (2013), analyses land rights and tenure influencing food security as a consequence. This model shows how land tenure practices can lead to either food security or insecurity. They further argued that a secured land tenure system, guided by a model, would generally lead to well defined and sustainable ownership structures, uses and management of resources. Chigbu and Klaus (2013) therefore contend that such a structure or model encourages defined property rights that lead to efficient land-based innovation and production systems. And this includes farming, devoid of unnecessary land rights and land tenure disagreements, the result of which can be increased food production, food availability and food security.

This research inspired by all three models, taps especially into that of Chigbu and Klaus (2013) as that directly connects land tenure to food security. This paper aims at testing the effectiveness of a responsible and fit-for-purpose land rights and land tenure model for this customary context in northwest Ghana. And examines its influence on food security of subsistence farmers, particularly non-landowners (migrants/settlers). According to Enemark and Mclaren (2017) a fit-for-purpose land administration system must be flexible, participatory and inclusive locally engineered. In other words, the FFP model uses the local political, socio-cultural etc. circumstances and practices to co-create the model to also fit their local purposes and solve their peculiar problems. Detail discussions on FFP model are contained in a paper preceding this one and submitted to Land MDPI journal - special issue for publication. This local involvement is what Galvagno and Dalli (2014); Ind and Coates (2013) referred to as co-creation. In this way, the model is potentially effective and successful, which Enemark and Mclaren describe as reliable, attainable and upgradable into the future. Thus, a requirement of fit-for-purpose system is to use the community to describe the tenure system and the kinds of evidence of the land rights currently in use (Zevenbergen et al., 2013). The model is then tested within the socio-cultural, political and economic environment where it will operate. Of course, based on communities' inputs and best practices of the effectiveness, functioning and possible obstructions to the model to address community land rights and tenure issues.

\subsection{Effectiveness of the models}

The FFP model in this paper targets the vulnerable and marginalised subsistence farmers in local communities. The effectiveness of this model is therefore measured based on its anticipated feasibility to assist these farmers access relatively strong land rights and obtain more secure tenure to boost local investments in farming for food to sustain their households (Nguyen et al., 2016; Zevenbergen et al., 2013). Referring to responsible and fit-for-purpose land administration and management; Enemark et al. (2014) believe such a model must be addressing the current constraints and allowing for incremental improvement over time to be regarded as effective.

\subsection{Functioning of the models}

In testing the functioning of the model, each participant (as an individual or in a group) engages in role-plays by dramatizing specific roles in the model as a trial of how it will function in practice. The available literature suggests that isolated implementation of either the current old or adopted model used elsewhere, cannot effectively promote strong land rights and secure tenure (Mulolwa, 2002). Rather a careful combination of various customary and formal land tenure practices, institutions and laws according to Mulolwa (2002), in addition to a strong attitudinal change is key. The stakeholders must also be desirous of success and committed to the proper functioning of the new model to ensure that it functions well, it is effective and efficient (Asperen and Mulolwa, 2006; de Vries ans Chigbu, 2017; Mulolwa, 2002).

\subsection{Obstructions to the effectiveness of models}

The review of the above models gives a clear indication that the effectiveness of models can be obstructed by a number of factors and in various ways. Capaldo et al. (2010) believe that vulnerability is the result of a recursive process. That is, current socio-economic characteristics and exposure to risks determine households' future characteristics and their risk-management capacity. The risk management strategies mentioned by Capaldo et al. (2010) invariably include how local land rights and tenure issues are being managed to make land available to people to farm and produce food for enhanced food security. A model can therefore facilitate and improve policy design and targeting. It implies that inappropriate management of risks like land rights and tenure issues, can obstruct the success of their model.

Mulolwa (2002) asserts that model effectiveness can be obstructed if dynamism in social land tenure relations are not upheld. The dynamism makes the model upgradable and allowing for incremental improvement (Enemark et al., 2014). This is because a model must be aimed to support individual, concurrent and communal rights. In which case emphasis may have to shift from ownership of land alone but to include rights to use land resources. Local tenure experiences have been mentioned also to be important but more so for tenure instruments/rules in the form of a model. For Mulolwa, rights and obligations as well as commitment and attitudinal change are necessarily captured in an effective model without which its effectiveness can be obstructed.

Chigbu and Klaus (2013) also insist that land tenure practices can lead to either food security or food insecurity. For a land rights and tenure model to be effective, there is the need for good land policies that focus on fair laws that consider the interests of the poor. They, Chigbu 
and Klaus (2013) believe that achieving this effectiveness cannot be feasible without the participation of rural people in the land rights and tenure strengthening process. Therefore, facilitating the co-creation of a model that can be said to be responsible and fit-for-purpose is fundamental (Enemark, 2017). Co-creation is the joint, collaborative, concurrent, peer-like process of producing some new object, model or value, both materially and symbolically (Galvagno and Dalli, 2014; Ind and Coates, 2013). Given the above perspectives, it implies that the lack of or inadequate local participation in model creation (i.e. whether co-creation or co-production) forms an obstruction to model success and must be addressed.

The focus of this paper therefore contributes to the discussion about the use of models to address socio-cultural challenges such as strengthening customary land rights and securing tenure. Further it needs to pay attention to the possible obstructions to the effectiveness of such models towards the realization of human aspirations like farming and food security.

\section{Study area and context}

The study area is located in the northwestern corner of Ghana as shown in Fig. 1.

In terms of land rights in the study area, the land rights are derived from the type of interest or title available to clans or families in the study area as briefly described below in Da Rocha and Lodoh (1999).

1) The allodial title: is the highest interest in land which is communally owned by clans or families.

2) The customary freehold interest: is family land use rights held perpetually as members of the allodial title.

3) The common law freehold right: is acquired by individuals or groups (usually outside the landowning group) through express grant from the allodial owner or customary freeholder. It is either in the form of sale, gift or other arrangements. It is usually held in perpetuity.
4) The 'leasehold' right: is acquired by individuals or groups also usually from outside the landowning group. It is given through express grant from the allodial owner, customary or common law freeholder in the form of sale and is subject to periodic renewal with the grantor based on the terms of the agreement usually 99 years.

5) Customary tenancies: are largely farming rights that landowners usually make available to non-landowners like settlers/migrants. The land rights of settler subsistence/smallholder farmers are derived from the customary freehold interest from landowning families, clans and sometimes individuals.

Generally, the farming arrangement in the study area and the rest of northern Ghana is a customary cropping (but not share cropping) agreement in which the land is given out 'free' to settler/migrant farmers who are usually non-members of the landowning group for farming on subsistence basis. It is important to note as contained in Nara, Lengoiboni and Zevenbergen (2020) that if the purpose is for large-scale commercial farming, the arrangement will be different. In return, the subsistence settler farmer provides a small portion of the yield i.e. "token gift" (estimated at a worth of seven euros or 40GHS), annually after harvest to the landowner. This gift given out is a way of affirming the mutual settler-landowner relationship. This cropping arrangement in the study area is unlike the share-cropping arrangement also known as "Abunu" or "Abusa" in southern Ghana.

The land rights model in use in the study area shows an ordered hierarchical structure in place as shown in Fig. 2. The reality however involves a complex relationship between landowners and settler farmers, among landowners and between males and females. It also involves all reference to tendana, tortina or tengansob as the custodian of all customary rights on land in the area. Besides, the land rights model here currently involves a dual system of customary and statutory/legal/ formal operating concurrently. The consequence of this situation is a seeming confusion characterised by little or no adherence to the rules and a consequent breakdown of order in the land administration and

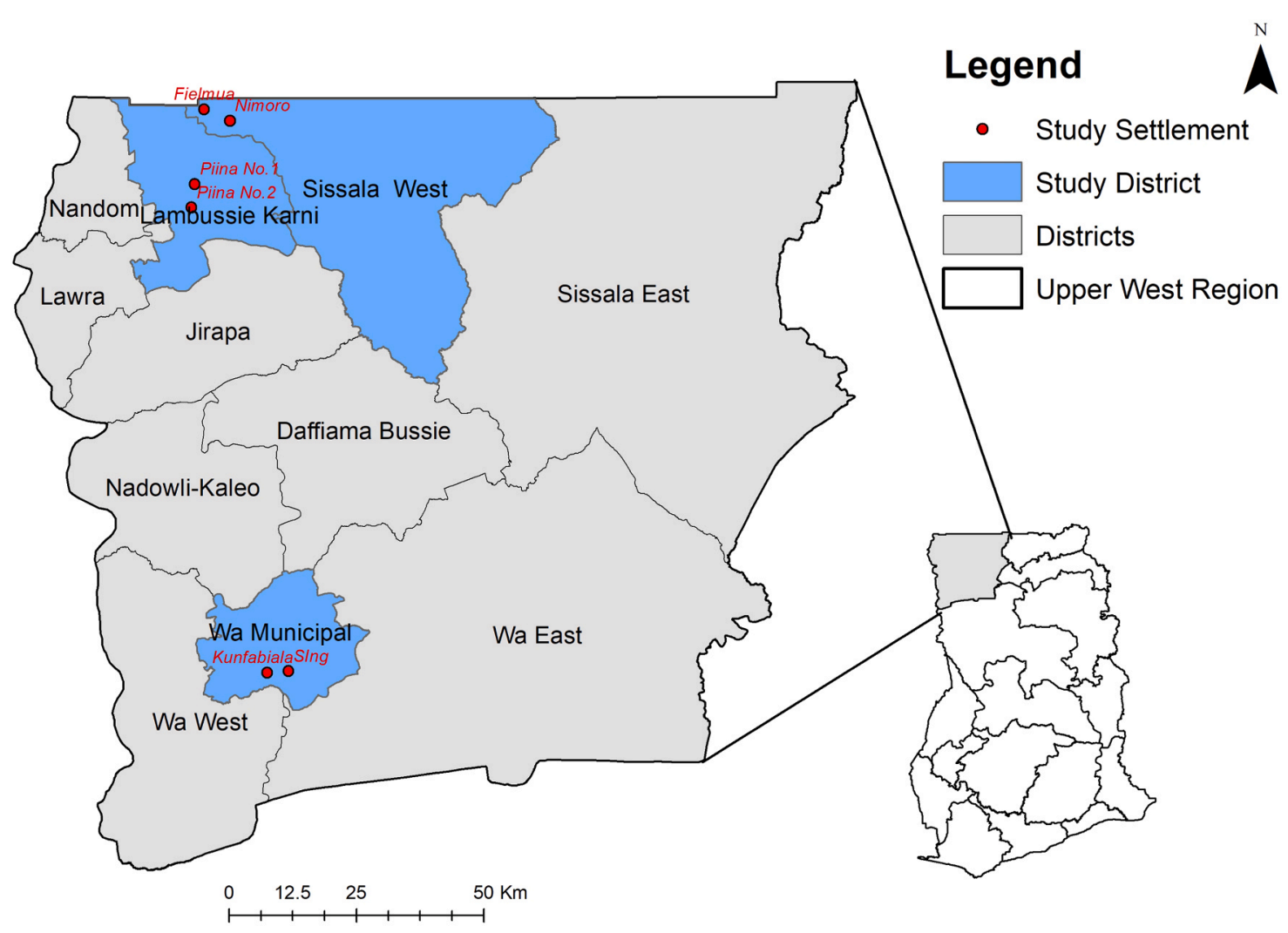

Fig. 1. Case study area (region and districts) in the regional and national contexts respectively. 


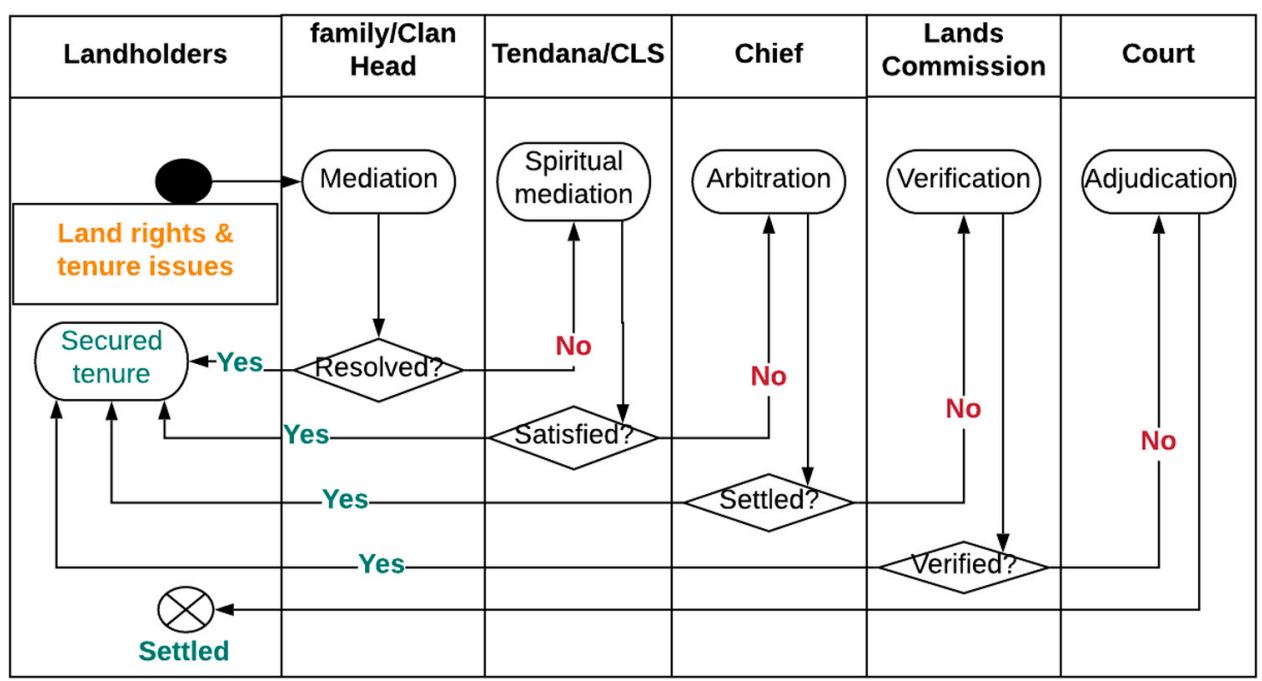

Fig. 2. Current land rights and tenure model.

(Source: Nara et al., 2020b)

management in the area. Hence, the need to redesign a more effective and functioning model to strengthen land rights and secure land tenure.

The normal order shown in Fig. 2 has broken down currently in practice, largely due to lack of an over-riding legislation. That is, there is no compulsion to abide by the model and there are hardly any sanctions for non-compliance to the model.Under the current scheme of things, a land issue from a landholder can be taken straight to Lands Commission or even the court instead of following the order. That is, from landholder - family or clan head - tendana - chief (when civil issues arise) - Lands Commission - court. These institutions have attempted to resolve some of these land tenure concerns but the results of such attempts have been unsatisfactory to the people. They did not strengthen land rights neither did they make land tenure more secure. This failure then emboldened the local people to participate and co-create their desired model in Fig. 3.

\section{Methods}

This research used mainly the qualitative approach of data collection in six communities (settlements) in all, two in the Wa municipality - Sing and Kunfabiala. The other four are Piina Number One and Piina Number Two in the Lambusie-Karni district and, Nimoro and Fielmua in the Sissala west district in Fig. 1. The data was collected in phases, briefly described below.

In phase 1, focus group discussions were used to solicit information from various categories of people in the community. For example, males and females, elders and youth, disabled and abled and, settlers and landowners. These groups responded to questions, some of which are contained in Box 1.

The responses received suggested the need for modification of the current land rights and tenure model to make it more effective in protecting land rights and securing tenure. The details have been presented in the results section later.

Key informant interviews that were conducted, targeted heads of landowning groups and heads of settlers as well as community level local government persons like assembly and unit committee persons. Other opinion leaders in the communities like retired influential civil servants and agricultural extension officers residing in the community were interviewed too.

Key persons in key institutions/organisations were interviewed. The first is a representative of the regional body governing lands on behalf of government i.e. the Lands Commission (LC). The second is a representative from the Wa Central Customary Lands Secretariat (WCCLSs) - an association of landowners' central office in charge of facilitating and documenting local land transactions. Furthermore, a private land documentation body, i.e. Meridia-Ghana also provided information in the institutional interviews via email through its representative.

Information from these government authorities and nongovernmental organisation - merridia regarding the Land tenure and the FFP model suggests that on expiration of a tenure, the land either reverses to the landlord otherwise, the settler farmer renegotiates it. To ensure tenure security, the stakeholders have to avoid deliberate violation of people's land rights under customary arrangements, get reliable and signed witnesses to land rights agreements, encourage documentation of tenure agreements that are sensitive to the marginalised and vulnerable. The LC and CLS asked for a shorter court adjudication period of not more than 5 years contrary to the current practice. They also called for lower cash charges, include non-cash charges as well

Box 1:

Discussion points for focus groups.

What's the current customary land rights and tenure model in this community?

What aspects are working well and yet needs modification?

What kinds of powers are needed to secure customary land rights and tenure?

What kinds of LRs included in the model can promote farming?

What will be the involvement (duties) of stakeholders to make the model work properly?

What level of cooperation (relationship) is expected among stakeholders for model to work well? 
as flexible payment terms. LC further admonished itself to uphold good land management practices (and as contained in its position on the FFP model).

In phase 2, group discussions were held with representatives of male and female groups. For instance, three disabled, three middle-aged and three elderly males formed one group for this phase of the data collection. In the same vein, three disabled, middle-aged and elderly females also formed the female group for their side of the discussion. All these discussions were aimed at fine-tuning the various issues raised in the earlier interviews and focus group discussions. Some of the topics/ questions discussed during this phase include the following in Box 2.

This discussion gathered responses about user requirements, role compatibility of people, institutions, laws \& stipulated periodic changes as well as strategies used elsewhere among others.

In phase 3, joint community workshops were organised for landowners and settlers from the same local jurisdiction affected by the same customary norms, laws and practices to assess the possibility for model success. The idea was to streamline seeming different assessments (i.e. expressed opinions, aspirations or understandings) of current rules and practices surrounding land dealings in order to merge them and arrive at a common united opinion/position about the model's success for stronger land rights and more secure tenure for all. The process of streamlining involved these questions/topics in Box 3. During the process of streamlining, the questions were raised and as varied opinions or suggestions were expressed, then smaller group discussions ensued. Later the representatives from the smaller groups in turns explained the reasons for their position to the rest. This generated further questions, explanations and discussions until a consensus was reached so that the common position was documented as presented in the results later.

The responses generated included stakeholder roles, positions, "redflags," responsibilities, timelines and measures to encourage compliance or deter violations.

Finally, in phase 4, separate community fora were organised to relay the outcome of the joint workshops and to receive final inputs from community members present for a final outcome representing their common position, interest, challenges and solution strategies.

The workability of this model was tested at the level of each community. Because this research is qualitative, different behavioural/attitudinal changes matter according to de Vries and Chigbu (2017) at this testing and the actual implementation stages. Model testing is a key activity undertaken during a model design process to assess its possible success and factors that may obstruct proper functioning, effectiveness and efficiency (Tsioptsias et al., 2016). The testing is also to crosscheck that the model is acceptable for its intended use and meets specified performance/user requirements and the test is also based on comparing best practices versus real-world situations (Rykiel et al., 2011). To maintain a model's effectiveness, there is continuous need for testing and for modelers and users to work closely together in the model implementation process to ensure its success (Tsioptsias et al., 2016).

During the FGDs and before the people rated the potential success or otherwise of the model, a dummy model was shown. The dummy model had community members purport to apply the overriding legislation mandating active roles of media, legal advocates in paralegal institutions, LC, CLS/tendana, chief, family head etc. in the process aimed at testing the model's functionality and potential success. Various tenure issues - ownership, transfers, disputes and rights clarification were dramatised i.e. tested in role playing scenario by mock offices and their representatives as in the new model. The participants identified and addressed potential land rights and tenure issues by way of providing possible solutions and connecting that to how it can possibly address their food security concerns in the area. The main purpose of this work was to envisage the outcome of a participatory community generated or co-created model. With the ultimate objective to address local land rights and tenure issues first, based on which productivity from land can be promoted. In the context of this work, it is to promote farming and secure food of marginalised and vulnerable subsistence farmers among others. It infers from the analysis of existing phenomena (land rights) policies (customary and formal practices) in order to predict how functional and successful a new model will be in a test-case using the communities themselves.

The testing was organised in the form contained in the New FFP model-testing flow chart in Fig. 3. It proved to be very easy to follow, informative and practical to understand and implement. It demonstrated that the overriding legislation (OL) served as a watch over all other units within the model. It was useful to the extent that because people did not want to get in the way of the law, respondents had to comply.

\section{Findings}

This section presents some non-structural and intangible aspects of the model to ensure it succeeds. These elements include attitudinal change like willingness and commitment to patronize the new model among all stakeholders. These issues were obtained from the various groups in the study area during the data collection process. Thus, government and other institutions for example the courts, security agencies, lands Commission, media, local communities, NGOs and CBOs would need to perform their tasks assigned in the new FFP model. Furthermore, the testing process aims to scrutinise and monitor the new FFP model to identify potential interruptions that can be quickly addressed for the anticipated reliability of the model when it is implemented. These are presented under effectiveness, functionality and obstructions to the model.

\subsection{Effectiveness of new model}

The process to solicit the people's assessment and opinions regarding

Box 2:

Issues discussed by group representatives.

What do subsistence farmers want to see in new model?

What kind of roles must be defined in the new model?

Who enforces these land rights?

Which institutions are involved in land administration and management in the model and in what ways?

How will people be rewarded or sanctioned for compliance or for violating the rules set in the new model?

What can make the model fail?

What kind of staff is needed in model?

What kind of laws (new or amended) are needed for new model to work well? 
Box 3:

Topic areas for Joint community workshops.

Who should own the land administration and management process as contained in the model?

What land rights or tenure insecurity indicators should be watched out for?

What will make land tenure and transaction costs affordable or not?

Who should pay what, to whom and at what intervals?

What is the level of local or outside involvement in the functioning of model?

What are the rewards and punishment systems in place to ensure compliance?

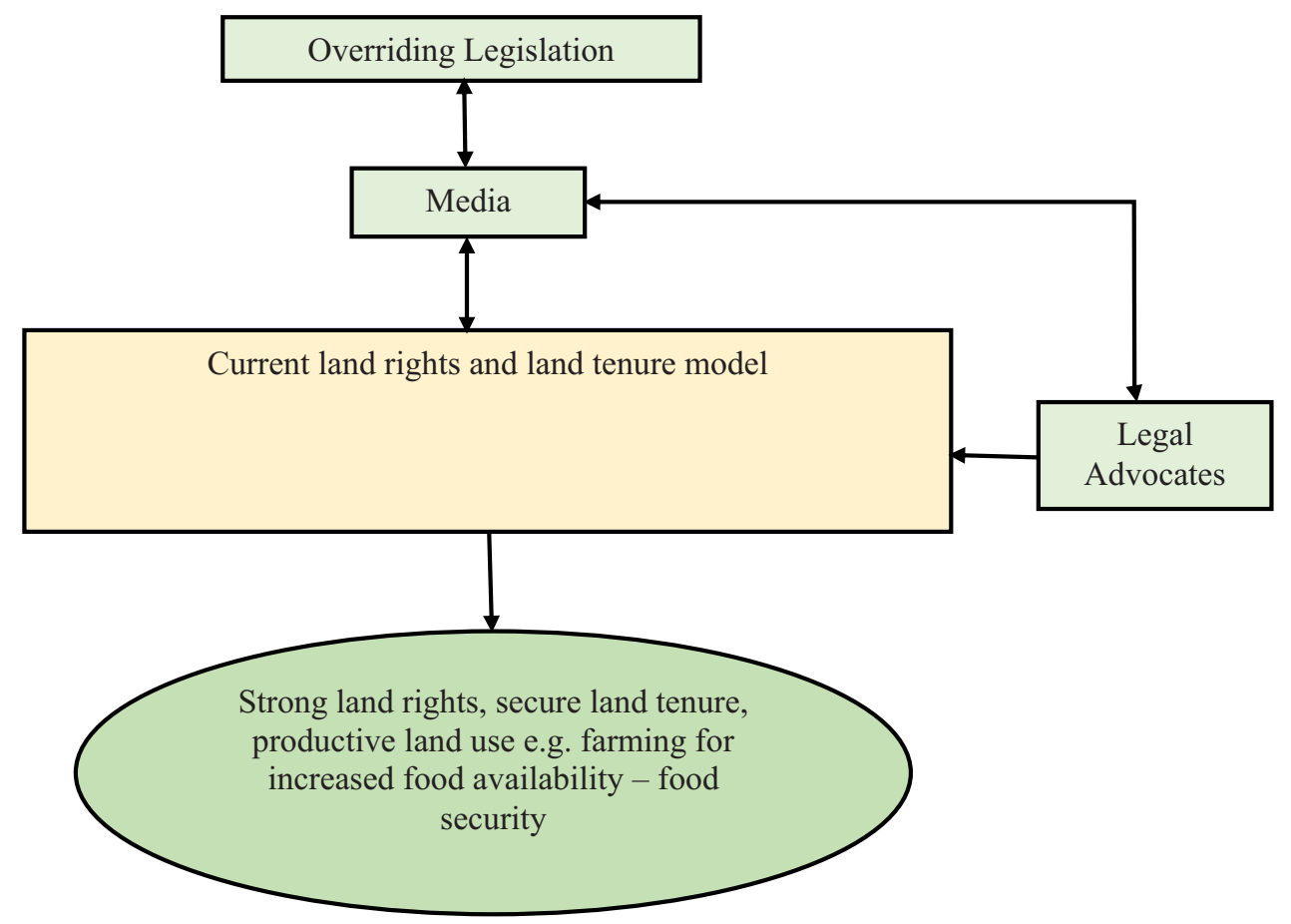

Fig. 3. New FFP Model-testing flow chart. Author's construct based on fieldwork, (2020).

the anticipated effectiveness of the new model is contained in the methods section. The community members expressed that the new model can function efficiently and effectively when all stakeholders are committed to it when implemented. This was generated through a process of consensus building as also explained in the methods section where opposing views were subjected to further discussions, explanations and sometimes lobbying within the groups until the desired agreement was reached. For instance, the participants mentioned that mutual respect for one another's land rights is a pre-requisite for the effectiveness of the new model. They also advised one another to endeavour to reach compromises quickly whenever land rights and tenure challenges emerge. In addition, they indicated that they will change their attitude from indifference to one of active patronage, contrary to the past. They said their acceptance of their active involvement in the complementary customary and formal processes for resolving land related challenges can promote the FFP model's effectiveness. This they said is necessary as the dual operation of both systems is already "deeply-rooted" in Ghana and the case study communities for that matter. One common expression during the workshops and community fora voiced by one settler elder was that:

"The government, through the formal/legal system has enormous power over all our customary institutions, laws and practices. So how can we fight it? We will rather cooperate with it for our common good." Another added "However, we expect a strong commitment from all stakeholders especially landowners, to the tenets of the new FFP model. Thus, we must be seen to be giving all categories of customary people their due rights, responsibilities and benefits otherwise the model will fail."

This emphasises communities' commitment to abide by the implicit hierarchical order of resolving their land rights and tenure challenges as well as handling other land related issues that are not necessarily conflicting. They also emphasized, recognising the primacy of customary norms and practices by their customs as well as the supremacy of the government's legal system as contained in Section 13(6)(a) of the new Land Act 2020, Act 1036. In this way, they admitted that they can attain the ultimate benefits of stronger land rights and more secure tenure for farming and food security in the following expression from one landowner (male elder) in the presence and on behalf of the rest that:

"We all agree that the new model will work when we all accept that some modifications to our current model are inevitable because this approach seems to suit us and works in other countries. First, the government's lead and oversight (political) role of the processes to strengthen land rights and secure tenure through enacting and 
strictly implementing an overriding legislation [partly in the Land Act 2020, Act 1036] to govern all land issues holds the key to an effective FFP model. Therefore, if government reneges on its core responsibility", "then the model will likely fail." Another elder concluded on that and continued thus "Similarly, the model will likely fail if other stakeholders (particularly we landowners) are not steadfast for its success. For instance, by the third sitting and third level of pursuing a particular case, the resolution must be reached to avoid unnecessary delays contrary to what pertains in our current land rights model."

The people also, expressed the workability of the new model because of its expected legal backing and strict adherence to its tenets. For instance, a spokesperson for women expressed their support for:

"Clarity of laws and roles on land rights and tenure [e.g. aspects of the Land Act 2020, Act 1036]. At least every individual or category of people will be clear on our rights, responsibilities and limitations. We will know that the current technological media space will publicise every issue emanating from land especially where an overriding legislation mandates the mainstream media to broadcast land rights and tenure issues." Another interjected thus: "the media is especially empowered, given the recent passage of the Right to Information Act in Ghana." Yet, another woman also added that "it will be easy for social media too, to quickly share any rights violations even from remote areas and immediately draw the attention of the mainstream media and legal advocates/paralegal support group to pick it up from there. We know that this will open the matter up for human rights institutions, NGOs and the state to know and get more interested and involved in safeguarding the land rights and tenure security of all but especially we [women], the weak and vulnerable in our communities. In this way, the new model will not fail as fearlessness and fairness will ultimately prevail."

The local people further expressed that their current tenure challenges have increased and become complicated. To them, it is because of youth disobedience for custom and elders due to influences of formal education, Christianity and Islam that weakened the hitherto high respect for customary processes of resolving land rights and tenure challenges. Meanwhile, these institutions were supposed to complement the efforts made by customary elders on land rights. That is why they stressed that the inclusion of an overriding legislation holds the prospects to secure tenure and strengthen land rights and make the model work effectively. This is because all will henceforth be compelled to commence with the customary institutions as contained in the new Land Act 2020, Act 1036 of Ghana. Thus, restoring reverence for useful customary practices, norms and institutions that were being disregarded. The customary system is still relevant because one elder said:

"We the elders are bequeathed with the right information based on several years of witnessing our ancestors handle similar challenges in the past. We are also in a better position than our youth and the government to know the rightful landowners or holders and associated tenure terms for each category based on these years of experience." "Furthermore", another continued "we [elders] have more sober tolerance to dutifully dispense justice, using ADR or simply supply the needed information to the courts for addressing any land rights and tenure issues/contestations with the use of the force of the laws. This will ultimately bind parties to its ruling." Yet another continued that "introducing the idea of renegotiation and documentation will make the model succeed because it will facilitate reference to past judgments and agreements. It will also create room for parties to correct any oversights in already concluded agreements." Also, a fourth elder contributing to the discussion opined that "the inclusion of the idea of obligatory fines for non-compliance and flexible, non-monetary payment options will all facilitate the feasibility of this new FFP model to not fail."
Invariably they emphasised that where there is no compulsion to abide by the new model in a law, weak application of the laws on it or indifference to it will likely make it fail. On the other hand, with increased and sustained sensitisation, penalty for non-compliance and avenues to use flexible payment options, the model will most likely succeed.

\subsection{Functioning of the new model}

The FGD participants support an ordered hierarchical structure of the FFP model (in Fig. 4). The participants contend that the land rights and tenure process must always first exhaust the local avenues in Fig. 2, of resolving land issues (contained in Ghana's Land Act 2020, Act 1036) before opting for other ADR, administrative or legal avenues. According to them, it may also involve NGOs at various levels if they are invited. The final stages may then be the verification of documentation on agreements by Lands Commission (LC) and adjudication by the courts as a last resort. They believe that this FFP model can function properly and can lead to some of their desired aspirations of strengthening land rights and securing land tenure if they all commit to it. And this may translate to the realization of their ultimate outcome (as farmers) of facilitating farming, increasing food production and food availability, which may enable them to attain some level of food security.

Landowner elders emphasised that the law in the new model must compel endorsement from them before disputes can be taken to the courts. In the functioning of the new model and for it to not fail, one landowner from Sing had this to say:

"We landowners and our CLSs (but not chiefs) have to be the legally mandated starting point for all land dealings. That is, rights and tenure issues like allocations, renegotiations, disputes resolution and endorsing all land related agreements or documentations." And added that, "chiefs' role on the model will remain complementary $i$. e. to deal with civil aspects while the land-based bodies will deal with the pure land issues." "Of course,", another interjected with supportive expressions from others around, "the LC and NGOs may come in to help resolve our land tenure issues/disputes at specific stages when earlier customary attempts may have ended inconclusively especially at inter-community levels. Meanwhile, we think that when all the local level efforts fail after a maximum of three attempts, the legislation must be explicit that the matter be referred to the courts. And at the courts, a specific period be stipulated - not more than three years, [there were interrupting interjections as some wanted fewer and others more years. But they finally agreed that three years is reasonable] within which the courts must dispense justice subject to one chance of appeal for each party." "In addition," another continued, "if the process exceeds the three-years duration, the legislation should automatically invoke "permanent vesting" of the disputed land in the state. This, we believe will compel us local people to hasten our resolution processes in order not to lose our land to the state. In addition, the model will function well and not fail when each stakeholder's role does not overlap with others."

There was consensus on the potential success of the new model as another landowner said that:

"The primary responsibility for the functioning of the new model rests with landowners and the local people to monitor and report any lapses in its functioning. We have built consensus in our communities that NGOs may play intervention/complementary roles using ADR mechanisms. Government's role will be to exercise overall oversight responsibility on all land matters including to monitor proper legal representation for the vulnerable and marginalised people. Government will also ensure speedy resolution of cases in courts and supervise proper and adequate reparation for those whose rights may have been violated and in favour of whom the courts have ruled on cases. Our caution is that strictly upholding vulnerable people's 


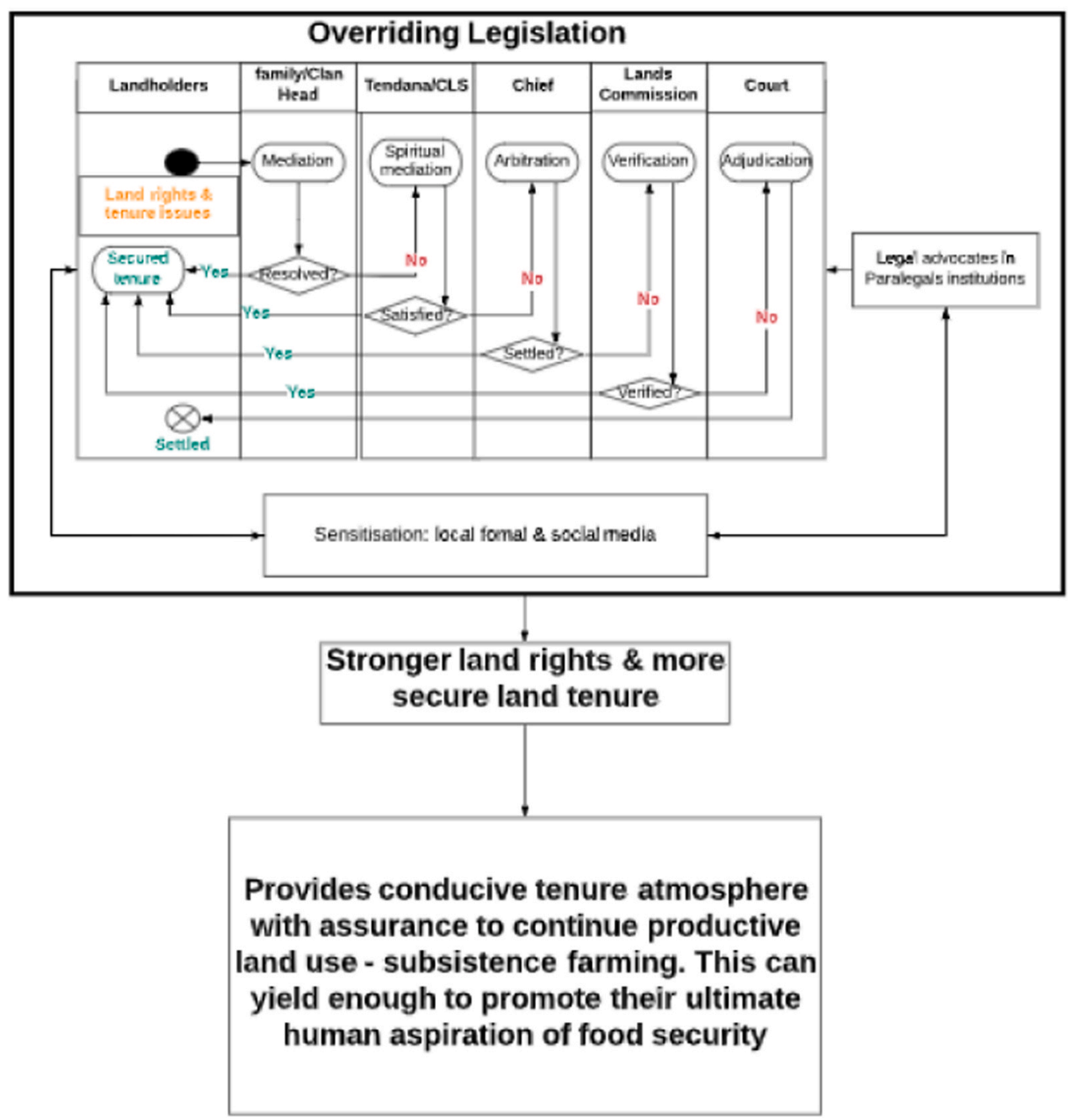

Fig. 4. Fit-for-purpose (New) customary land rights and tenure model.

(Adapted from Nara et al., 2020b)

rights will instill confidence of everyone in the new model so that it will not fail."

For the people, any neglect of the good aspects of customary norms and practices will affect the proper functioning of the model. They emphasised that no land case can be properly resolved without inputs from elders and local people who are the custodians of customs including on land. Consequently, one disabled, expressing on behalf of the others indicated that:

"We, the disabled people advocate that the operation of the model have to make some concessions for us as custom demands. We therefore suggest stiffer punishments for people who trample upon our land rights. In addition, cases involving us may be given priority over others involving abled bodied people. The new model we think will function well if the CLSs dutifully record all land transactions and agreements both the already existing and renegotiated ones."

Also, one settler participant expressing for all settlers raised that:

"Any arbitrariness in applying the new model based on the overriding legislation will obstruct its proper functioning. Staff of the CLSs can be composed of a mix of both land-based professionals and customary landowners (through collaborations and cooperation) for complementary handling of all land issues including rights and tenure disagreements. Since we are not landowners, we cannot think of being part of the CLSs even though it is good to consult us if any land deal involves the lands we are tilling otherwise when we resist, the model will fail. As users of the land, we know the owners better than some current generation landowners."

Settlers were quick to add that the functioning of the new model will likely be obstructed if landowners do not do anything to assure them (settlers) of some relief, as lands are increasingly getting scarcer in both rural and urban areas. For instance, another settler said that:

"When landowners engage in secret land sales, settlers will likely resist any development activities on their 'lands.' However, once we settlers can claim up to $40 \%$ of benefits or compensation accruing to or for the land we subsist on, plus a non-negotiable "free" land of between one acre in urban areas to two hectares in rural areas, then the model is good and will function successfully. It will not fail.'

\subsection{Possible obstructions to effectiveness of new model}

Regarding important assumptions for which the effective functioning of the model is dependent, the respondents asserted that if the communities own the model, it will succeed otherwise it may become 
ineffective. They also mentioned that particular tenure insecurity indicators to be constantly monitored by all stakeholders. For instance, a common call from settler FGDs expressed by one was that:

"When local manipulations, arbitrary seizures and sale of lands by landowners cease, we settlers will stop land encroachments, refusal to attend/participate in communal land tenure meetings or issuing of various threats - sometimes we just cannot help it." Another added that "if the courts persistently delay in dispensing justice as we witness now, it will obstruct the effective functioning of the model. Furthermore, when "winners" in any land disputes also receive payments of compensation from losing parties through either customary settlement or court system, then the model will function effectively. Otherwise, as in the current situation (in Fig. 2) without compulsion, there is no incentive to abide by conventional settlement of land rights and tenure disagreements. It will be a waste of our time and our little money in transportation and other costs to and from court. So why will we comply?"

Again, some FGD participants mentioned that persistent arbitrary land conversions and unannounced developments by outsiders (land developers) could cause the new model to malfunction in their context. To that effect, another settler added that:

"All stakeholders especially the landowners have to watch out and work against secret land sales, non-consultation with settlers and non-renegotiation stipulations when the new model is implemented. For the model to function effectively and efficiently, transparency is essential for us. Moreover, whenever land rights and tenure related misunderstandings happen, we all have to speedily deal with them before they worsen. Thus secrecy, greed and disregard for our [settlers] land rights will obstruct the proper functioning of the model."

On the obstacles that may stand in the way of an effective and efficient model from the perspective of landowners, a landowner (tortina in Nimoro) mentioned that:

"We expect that settlers and other secondary land rights holders will abide by the overriding legislation and indeed the new model. In addition, outsiders (except government) do not have to meddle in local land rights and tenure security affairs until they are directly invited. For us, such intruding outsiders may be misconstrued to have a stake that opposes ours. We will be reluctant to comply with the new model in such instances because of suspicion of biases from outsiders (intruders). In addition, if we are disregarded in handling land issues including resolving land rights and tenure challenges, we will not also comply with such outcomes or verdicts and this will obstruct the proper functioning of the new model. We want to be directly involved especially regarding customary aspects as that will facilitate the proper functioning of the new model."

Some of the research participants (particularly women) also indicated that at the sensitisation front, the mainstream media and customary channels at local gatherings have to endeavor to praise publicly on acts of compliance with the new land rights and tenure model and the legislation backing it. On the other hand, they suggested that non-compliant persons and actions must receive public condemnation to discourage further or other violations. Additionally, they pointed out that high, cash-based and non-flexible costs to parties trying to resolve their tenure disagreements may obstruct the model's effectiveness as such parties will not even patronize it or skip some stages of the model's order which can cause its failure. Women therefore suggested flexibility in fining and receiving fines. For instance, the use of manual labour and public apologies, use of farm produce to redeem charges of offenders will be effective and cause the model to function well. Also, the victims of land rights violation could be entitled to some claims through those settling the tenure disputes from payments made by the defeated party."
Finally, settlers mentioned that an obstruction to the success of the new model will be the current practice of making both parties pay monies to customary elders for resolving disagreements. Instead, elders at the end of resolving any disagreement have to impose fines on the losing party alone as it is practised by the courts. The victorious party walks away without any charges and in addition, receives part of the fines as compensation for the inconveniences and damages suffered before, during and after the litigation.

\subsection{Testing the model}

The researcher conducted a summary exercise to test the feasibility and success of the new model among 12 representatives in each community using a Likert scale. The direct question posed to the participants of the joint workshops was:

The new land rights and tenure model will function effectively, efficiently and successfully. To what extent do you agree or disagree. Explain your choice.

The options to them were: Strongly agree, Agree, Disagree, Strongly disagree.

There was that fear of exposure by the media (mainstream, customary and social) which 'compelled' some people to comply. During the role play session, respondents were asked why they were complying with almost the same processes that were hitherto disregarded and they pointed to the overarching legislation.

The least used institution within the model was the legal advocates. We therefore asked whether it should be taken out of the model. The people said it was necessary to maintain it to empower the vulnerable and marginalised people. And added that the absence of advocates can be a weakness that some powerful people may want to exploit later on.

The results from the joint community workshops show varying anticipated success levels. The reasons for these differences are due to the nature of the inherent existing relationships between and among communities.

Generally, all the communities foresee the model's success largely, but on conditional basis. For instance, landowners state that when settlers and all secondary land rights holders comply and observe their roles in the new model, then it will succeed. Settlers' condition for model's success is transparency and respect for everyone's land rights. In general, as shown in Fig. 5, both landowners and settlers in Piina were the most optimistic (i.e. strongly agree) about the success of the new model. Out of the three pairs of communities visited, the people of Piina number 1 and Piina number 2, report experiencing minimal land rights and tenure challenges. Some of the reasons they adduced for this include mutual respect for peaceful co-existence for common development. They also desire to uphold ancestral agreements and they practice inter-ethnic marriages to strengthen their oneness. Furthermore, they reported of engaging in cordial daily interactions between the two groups such as at local gatherings (market, funerals and festivals). These interactions are very minimal between Fielmua and Nimoro communities. In Sing, one inter-marriage was mentioned yet there is less tension between landowners and settlers. There is however, some slightly related tension among landowners in Sing at the time of compiling this paper due to an impending land compensation package which they are about to receive from government. The compensation package is in respect of part of the land taken by government in Bamahu, Wa to establish the University for Development Studies (UDS) which has now been converted to University of Business and Integrated Development Studies (UBIDS). The youth are suspicious that elders may want to withhold the chunk of the money to the disadvantage of they the youth, hence their apprehensions.

\section{Discussions}

This research aimed at testing a land rights model referred to as responsible and fit-for-purpose that is holistic and locally engineered i.e. co-created with local communities. It was set to assess/test the possible 


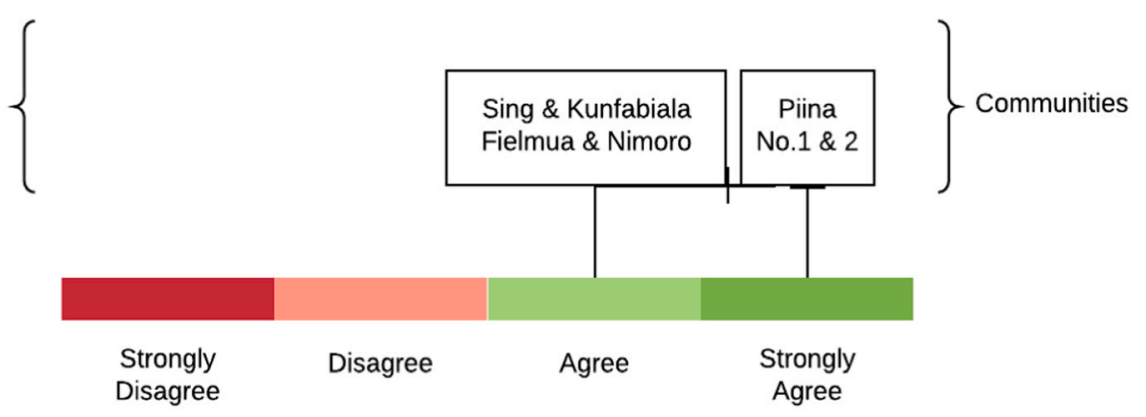

Fig. 5. Results of testing communities' trust in new model's success on Likert scale.

effectiveness and proper functioning of and, likely obstructions to the model towards strengthening land rights and securing land tenure. It then tested how these land rights (strong or weak) may be influencing food security as a consequence. Its target group is predominantly the vulnerable and marginalised subsistence farmers in local communities. The test is based on the new model's anticipated effectiveness to assist these farmers' access relatively strong land rights and more secure tenure to boost local investments in farming for food to sustain their households.

Testing land rights and tenure model in the communities was done to estimate the people's level of confidence in the workability of the model. It was tested through beneficiaries' responses, choices and voting in terms of numbers in a role playing (or drama) session. The process showed who or how many agree to or oppose the effectiveness of various aspects of the model when implemented. That is, the extent to which indication shows on the ground and drawing lessons from theory to support the interpretations of test scores obtained from users of the model. Again, the people used everyday land rights and land tenure issues/problems so that their attempts to address them will reveal the possible obstructions and feasibilities. Some acted as victims while others acted as persons and institutions in the model and acted using the arrangements in the model to deal with the problem. In the process, various issues came up and were dealt with to the satisfaction of all present.

\subsection{Effectiveness of new model}

The effectiveness of a model means that it is able to meet specified (and in this case anticipated) performance requirements, targets and aspirations as opined by Rykiel et al. (2011). In this case, once the model is known and deemed by the people as capable of strengthening land rights and securing tenure in order to promote farming and ensure food security, then it is considered to be effective. For Mulolwa (2002), an effective model may not be entirely new to the local people as in the sub-Saharan African context. Rather, it is usually a combination of already familiar principles, practices and systems of local people with some elements of other models in use elsewhere. In line with Mulowa, this new model used the existing and current customary norms, practices and rules in combination with other experiences as contained in literature to co-design the new model. Boudreaux and Sacks (2009) posit that effective models are those that exist with the government playing a lead and oversight role to protect the weak. That is, the fundamental role of national government to provide an overarching legislation (Nara et al., 2021). For instance, Section 15 of Ghana's new Land Act 2020, Act 1036 and an efficient adjudication system lend credence to this new model and can facilitate its effectiveness to enable local people meet their aspirations. This implies that as Mulolwa hinted earlier, effective models are locally engineered i.e. co-created by working with local people. In that light, this fit-for-purpose (FFP) model was co-created with some level of external facilitation. Regarding external assistance, the mainstream media involvement in this FFP model can help sensitise people about it and its abuses to make it effectively strengthen land rights and secure tenure. This is expected to promote local farming for food security. The effectiveness of the new FFP model may also be assured given the fact that it is based on the current local means of information using local "attention-seeker" gadget for making announcements and at local meetings. This strategy is corroborated by Bugri (2010), who posited that effective models also make use of local channels of information flow and sensitisation. This further corroborates the assertion of Ballard et al. (2013) who opine that "even though information alone is clearly insufficient yet, it can be a powerful tool to create awareness, acceptance and patronage of a new system, model or policy." In addition to mainstream and local media, this paper contends that under current circumstances of high need for information by especially the youth and middle-aged people, social media can also play a vital role through quick dissemination of information on land rights issues. This can make effective this FFP land rights and tenure model.

\subsection{Functioning of the new model}

According to Allameh et al. (2013); Lynn (2015); Srikanth and Jomon (2013); Yadav and Rangnekar (2015) better clarity and less ambiguity regarding individual group or organisation roles can facilitate functioning and performance significantly. Therefore, the relatively clear roles of stakeholders in this new FFP model can make it function properly where positions in the hierarchy are respected as such. For instance, the CLSs and tendamba for that matter being part and in fact the first point of call in all land matters ranging from allocation through documentation to dispute resolution can make the model function smoothly. On the backdrop of this, it requires the non-involvement of chiefs in land issues in this area except civil issues connected with land matters.

Speedy resolution of disputes can also facilitate the functioning of the FFP model. Ostrom and Hanson (2010); Swigert and Farrell (1980) in different studies found that cases adjudicated promptly result in higher conviction rates thereby instilling confidence in the functioning of the system (in our FFP model) than those which are delayed. But Lentz posited that using the concept of "traditional" local communities as the quasi-natural basis of grass-roots democracy, as the Ghanaian decentralisation project implicitly did, is highly problematic.And referred to it as a "Pandora's box rather than a panacea" (Lentz, 2001). The better solution therefore for model performance to occur participants argued is that, government (holding oversight power on all matters in the country) may vest in itself disputed land that remain unresolved after three to five years. Furthermore, if after five more years (making it 10), parties do not reach a compromise by themselves, then they both lose the land permanently to the state. In this way, a ten-year moratorium (period for a compromise) may be made available to parties and if they fail to reach that compromise, then the land remains state property forever for public good which may ultimately restore "peace" once there is "nothing to fight over." This is possible as local people already claim (rightly or wrongly), that government - the law is "bigger" (i.e. more powerful) than its citizens and they cannot fight/disobey it.

For proper functioning of a model, consultation is key (Gifford et al., 
2005; Green and Herget, 1991). Hence, consulting secondary land rights holders if their land is involved in disputes, allocation, documentation etc. may facilitate the model's smooth functioning. And this is very much part of this FFP model.

In addition, regarding compensation payments and receipts, it is important to note the almost perpetual interest of secondary land rights holders in the context this study area. In that light, for them to help in the proper functioning of the model, their interest beyond current developments on the land is key. Once, they are assured of this, their support and cooperation will enable the model to function well. Karia and Omari (2017); Mabaso and Dlamini (2017) said there is a statistically significant relationship between compensation receipts, satisfaction of beneficiaries and their cooperation leading to organizational (system or model) performance. And therefore, suggested that compensation should be provided expeditiously so as to enhance performance of both employees and organization (as with local people and their land rights and tenure model). Therefore, simple involvement of and co-creation with local people in land tenure model design, monetary payments for compulsorily acquired lands, resettlement packages and other forms of respite can attract local support for the functioning of this FFP model.

\subsection{Possible obstructions to effectiveness of new model}

Capaldo et al. (2010) believe that socio-cultural issues/challenges can best be solved through the use of laid-down systems like an FFP model which is effective. But generally, system or model effectiveness may be obstructed where some or all of its aspects are neglected, manipulated or taken for granted by those placed in authority to enforce it. And may be due to socio-cultural, political or economic expediencies among others. Also, as Chigbu and Klaus (2013) put it, inadequate participation or what Galvagno and Dalli (2014); Ind and Coates (2013) refer to as co-creation (when it is lacking), can significantly obstruct model effectiveness. This was clearly demonstrated when during the role-playing sessions in the study area, some victims of land violations refused to cooperate in abiding by the tenets of the model and it eventually broke down. For Mulolwa, rights and obligations as well as commitment and attitudinal change are necessary for an effective model. Indicating that a deviation from these can obstruct the effectiveness of any model. In support of this assertion, there were instances when the right of a settler to be consulted by landowner before attempting to change his/her land rights were neglected. Such victims resisted anybody who entered the land as a new owner/developer of land. These victims/settlers stated that the current land rights model had been in use since time immemorial without much difficulty. And emphasised that landowners must employ similar practices used in the past to avoid any possible failure of the new model. As change is inevitable, significant transformations occurred in the past regarding land ownership, transfers etc., yet, little social tension and tenure insecurity were prevalent. However, since Ghana's independence, many of its communities experienced population explosion and urbanisation following government upgrading of their political or administrative statuses. This seems to influence arbitrary seizures and sale of lands by landowners and this compelled secondary land rights holders, particularly settlers and others who feel marginalised to begin disregarding (by manipulating, neglecting or taking for granted) the very model - norms and practices that were largely regarded as peaceful. In addition to that, the concurrent operation of the dual land management system (formal/legal and customary) in Ghana and the study area caused some confusion. People sometimes do not know whether to go by the customary or legal/statutory system. Furthermore, the legal/statutory system did not seem to provide the needed justice delivery that the customary people expected and made many to resort to other ways of protecting their land rights. For instance, the formal system was thought to issue non-deterrent sanctions or showing partiality in adjudication, thereby causing disaffection among local people who prefer other undesirable options.

Customary agreements based on the current (ancestral model using oral tradition) have some renegotiation clauses as and when the need arises. However, in an increasingly commodified land-dependent society of today, stipulated time-bound explicit renegotiation periods may be required without which the FFP model functioning may be obstructed. Land issues that are characterised by non-transparency, external interference, less sensitisation with too much emphasis on money were mentioned by the people to be capable of obstructing the functioning of the model since the wealthy people will always have their way and the weak losing out. Hence, the current Land Act 2020, Act 1036 in Section 13(3), emphasises transparency by fiduciaries of land and failure of which attracts legal sanctions.

\section{Conclusion and policy recommendations}

This research aimed at testing the co-created model, referred to as responsible and fit-for-purpose - FFP. It assesses land rights/tenure security influencing food security as a consequence. The test is based on the model's anticipated effectiveness to assist farmers access relatively strong land rights and more secure tenure to boost local investments in farming for food to sustain their households.

This paper tests this model using communities' own aspirations, needs, suggestions and commitments (i.e. user requirements) based on the following measurement criteria set out in the objectives. They are, factors that may promote the effectiveness of the model, ingredients for proper functioning of the model and the possible obstructions to the effectiveness of the model.

The outcome shows that the challenges in the communities' current land rights and land tenure model have been identified. Secondly, the solutions to these constraints were co-created together with the communities. This qualifies the designed model as fit-for-purpose - FFP which Enemark et al. (2014) believe "to address current constraints and allowing for incremental improvement over time to be regarded as effective." In other words, the FFP idea uses the local political, socio-cultural etc. circumstances and practices to co-create the model to fit their local purposes and solve their peculiar problems.

Literature suggests that isolated implementation of either the current old or adopted model, cannot effectively promote strong land rights and secure tenure (Mulolwa, 2002). This informs that a combination of models is the best strategy. But this must be in addition to a strong attitudinal change and commitment from all stakeholders. The communities demonstrated willingness and commitment through their active participation during the co-creation of the model. Change/risk management as a major dimension of the implementation of this model is emphasised. This is because implementation of well targeted and coordinated projects (model in this case) within the organisation can provide major organisational changes leading to effectiveness and efficiency (Kuzmanova and Alexandrova, 2017). Meanwhile, proper management is required to ensure the effective implementation (Munassar et al., 2013). All projects involve an element of organizational change and so both project management (like model implementation) and change management have a role to play in delivering desired changes or aspirations (Pollack, J., 2017). Therefore, appropriate risk management strategies referred to earlier, can help reduce landlessness and make land available for farming to produce food for improved food security. The clear roles of all stakeholders in the new FFP model can facilitate and improve public policy design and targeting. The assurance of appropriate management in the new model is the inclusion of customary institutions, people and practices. It gives dynamism in social land tenure relations needed in this model without which its functioning will be obstructed. This model de-emphasises land ownership and emphasises its use rights, thereby re-assuring people of its sensitivity to their interests.

Finally, this model may require some adjustments during implementation to fit in each unique customary land management system to 
be adequately effective Particularly, the involvement of government actors which was not done in this test.

\section{Acknowledgement}

This research funder the Netherlands Universities Foundation for International Cooperation (NUFFIC), now known as Orange Knowledge Programme (OKP).

\section{References}

Allameh, S.M., Harooni, A., Chaleshtari, M.S., Asadi, A., 2013. Investigate the relationship between variables and role clarity effects on the perceived service quality of front line employees (Studied on the Clerks of the Keshavarzi Bank in the Province of Chaharmahal-E- Bakhtiary). Int. J. Acad. Res. Bus. Soc. Sci. 3 (5), 127-138.

Asperen, P.V. a N., \& Mulolwa, A. (2006). Improvement of Customary Tenure Security as Pro-poor Tool for Land Development - A Zambian Case Study. In 5th FIG Regional Conference (pp. 1-15).

Ballard, T.J., Kepple, A.W., \& Cafiero, C. (2013). The Food Insecurity Experience Scale: Development of a Global Standard for Monitoring Hunger Worldwide.

Boudreaux, B.K., \& Sacks, D. (2009). Land tenure security and agricultural productivity.

Bugri, J.T. (2010). Understanding changing land access and use by the rural poor in Ghana.

Capaldo, J., Karfakis, P., Knowles, M., \& Smulders, M. (2010). A model of vulnerability to food insecurity (No. 10-03). ESA Working paper.

Chigbu, U.E., \& Klaus, M. (2013). Insecurity - Generating System of Land Tenure and its Impact on Rural Development: Evidence from Uturu, Nigeria.

Cotula, L., \& Neves, B. (2007). Changes in 'Customary' Land Tenure Systems in Africa. Changes in "customary" land tenure systems in Africa.

de Vries, W.T.; Chigbu, E. (2017). Responsible Land Management-Concept and application in a territorial rural context Verantwortungsvolles Landmanagement im Rahmen der Ländlichen Entwicklung.

Enemark, S. (2017). A Fit-For-Purpose approach to Land Administration in Africa in support of The 2030 Global Agenda (pp. 15-17).

Enemark, S., Bell, K.C., Lemmen, C., \& McLaren, R. (2014). Fit-For-Purpose Land Administration. International Federation of Surveyors (FIG). https://doi.org/https:// www.fig.net/resources/publications/figpub/pub60/Figpub60.pdf.

Enemark, S., \& Mclaren, R. (2017). FIT-FOR-PURPOSE LAND ADMINISTRATION: DEVELOPING COUNTRY SPECIFIC STRATEGIES FOR IMPLEMENTATION STIG ENEMARK Professor Emeritus of Land Management, Aalborg University, Denmark Director, Know Edge Ltd, UK Paper prepared for presentation at the " $2017 \mathrm{~W}$.

Federal Ministry of Food and Agriculture (BMLE). (2015). Understanding global food security and nutrition Facts and backgrounds, 29. Retrieved from (www.bmel.de/ publikationen\%0AThis $>$.

Galvagno, M., Dalli, D., 2014. Theory of value co-creation: a systematic literature review. Manag. Serv. Qual. 24 (6), 643-683. https://doi.org/10.1108/MSQ-09-2013-0187.

Gifford, J., Fiona, N., George, L., 2005. Employee involvement information. Consult. Discret. 1-111.

GREEN, R.-J., HERGET, M., 1991. Outcomes of systemic/strategic team consultation: III. The importance of therapist warmth and active structuring. Fam. Process 30 (3), 321-336. https://doi.org/10.1111/j.1545-5300.1991.00321.x.

Ind, N., Coates, N., 2013. The meanings of co-creation. Eur. Bus. Rev. 25 (1), 86-95. https://doi.org/10.1108/09555341311287754.

Karia, A.O., Omari, S., 2017. Importance of compensation and benefits on performance of public water utilities in tanzania importance of compensation and benefits on performance of public water. Afr. J. Bus. Manag. 9-18 (January 2015).
Kuzmanova, M., \& Alexandrova, M. (2017). Change Management and Project Management Integration. Leadership \& Management: Integrated Politics of Research and Innovations LIMEN, (December 14), 204-212. Retrieved from https://www. researchgate.net/publication/323935063_Change_Management_and_Project Management Integration Survey Evidence.

Lentz, C. (2001). Contested boundaries: decentralisation and land conflicts in northwestern Ghana. Bulletin de l'APAD.

Lynn, G., 2015. The effect of vision and role clarity on team performance. Pressacademia 4 (3), 473. https://doi.org/10.17261/pressacademia.2015313067.

Mabaso, C.M., Dlamini, B.I., 2017. Impact of compensation and benefits on job satisfaction. Res. J. Bus. Manag. 11 (2), 80-90. https://doi.org/10.3923/ ribm.2017.80.90.

Mulolwa, A. (2002). Appropriate Tenure Model for Sub-Saharan Africa.

Munassar, F., Ghanim, A., Ahmad Dahlan, A.R., 2013. Change management and its contribution to the success of IT project implementation. Int. J. Inf. Commun. Technol. Res. 3 (4), 134-140.

Nara, B. Baslyd, Lengoiboni, M., \& Zevenbergen, J. (2020a). Implications of Customary Land Rights Inequalities for Food Security: A Study of Smallholder Farmers in Northwest Ghana. Land.

Nara, B. Baslyd, Lengoiboni, M., Zevenbergen, J., 2020b. Infuences of Community Land Rights and Tenure Security Intervention Processes on Food Security in Northwest Ghana. In: De Vries, W.T., Bugri, J.T., Mandhu, F. (Eds.), Responsible and Smart Land Management Interventions An African Context, 1st ed. Taylor \& Francis Group, Boca Raton, pp. 49-62.

Nara, Baslyd B., Lengoiboni, M., Zevenbergen, J., 2021. Assessing customary land rights and tenure security variations of smallholder farmers in northwest Ghana. Land Use Policy 104, 105352. https://doi.org/10.1016/j.landusepol.2021.105352.

Nguyen, T.H.T., Tran, V.T., Bui, Q.T., Man, Q.H., Walter, T. de V., 2016. Socio-economic effects of agricultural land conversion for urban development: case study of Hanoi, Vietnam. Land Use Policy 54, 583-592. https://doi.org/10.1016/j. landusepol.2016.02.032.

Ostrom, B., \& Hanson, R. (2010). Achieving High Performance: A Framework for Courts.

Peters, P.E., 2013. Land appropriation, surplus people and a battle over visions of agrarian futures in Africa. J. Peasant Stud. 40 (3), 537-562. https://doi.org/ 10.1080/03066150.2013.803070.

Ruerd, R., \& Policy and Operations Evaluation Department (IOB) Ministry of Foreign Affairs. (2011). Improving food security. A systematic review of the impact of interventions in agricultural production, value chains, market regulation, and land security. The Hague, The Netherlands. Retrieved from www.minbuza.nl \%7C www. rijksoverheid.nl.

Rykiel, E.J., Thacker, B.H., Doebling, S.W., Hemez, F.M., Anderson, M.C., Pepin, J.E., ... Sargent, R.G. (2011). Testing ecological models: The meaning of validation. Proceedings of the 2011 Winter Simulation Conference, 90(October), 41. https://doi. org/10.1016/0304-3800(95)00152-2.

Srikanth, P.B., Jomon, M.G., 2013. Role ambiguity and role performance effectiveness: moderating the effect of feedback seeking behaviour. Asian Acad. Manag. J. 18 (2), 105-127.

Swigert, V.L., Farrell, R.A., 1980. Speedy trial and the legal process. Law Hum. Behav. 4 (3), 135-145. https://doi.org/10.1007/BF01040316.

Tsioptsias, N., Tako, A., Robinson, S., 2016. Model validation and testing in simulation: a literature review. Open. Ser. Inform. 50 (6), 6.1-6.11. https://doi.org/10.4230/ OASIcs.SCOR.2016.6.

Yadav, M., Rangnekar, S., 2015. Service quality from the lenses of role clarity and organizational itizenship behavior. Procedia Soc. Behav. Sci. 189, 395-405. https:// doi.org/10.1016/j.sbspro.2015.03.236.

Zevenbergen, J., Augustinus, C., Antonio, D., Bennett, R., 2013. Pro-poor land administration: principles for recording the land rights of the underrepresented. Land Use Policy 31 (March), 595-604. https://doi.org/10.1016/j. landusepol.2012.09.005. 